\title{
Deep seismic reflection profiling across the Northern Fossa Magna: The ERI 1997 and the JNOC 1996 seismic lines, active faults and geological structures
}

\author{
Driss Elouai ${ }^{1}$, Hiroshi Sato ${ }^{2}$, Naoshi Hirata ${ }^{2}$, Shinji Kawasaki ${ }^{3}$, Toru Takeshita ${ }^{1}$, Naoko Kato $^{2}$, and Tetsuya Takeda ${ }^{2}$ \\ ${ }^{1}$ Department of Earth and Planetary Systems Science, Graduate School of Science, Hiroshima University, \\ 1-3-1 Kagamiyama, Higashi-Hiroshima 739-8526, Japan \\ ${ }^{2}$ Earthquake Research Institute, University of Tokyo, 1-1-1 Yayoi, Bunkyo, Tokyo 113-0032, Japan \\ ${ }^{3}$ JGI Inc., 1-5-21 Otsuka, Bunkyo, Tokyo 112-0012, Japan
}

(Received June 7, 2004; Revised November 25, 2004; Accepted December 3, 2004)

\begin{abstract}
The Northern Fossa Magna is a Miocene failed rift and due to subsequent shortening, its basin-fill forms a fold-belt associated with active faults. Seismic reflection data across the middle part of the northern Fossa Magna acquired in late 1990s were reprocessed to reveal the deep geometry of active faults. The reprocessed seismic sections portray the folded and faulted structure of the Neogene basin-fill. The deeper extension of the Western Nagano Basin active Fault (WNBF), which has been revealed for the first time, can be traced down to $4 \mathrm{~km}$, as a reverse fault dipping $40^{\circ}$ westward. In the western part, the Itoigawa-Shizuoka Tectonic Line (ISTL) active fault is presented as an emergent thrust dipping 30-35 eastward. Based on the seismic profiles, surface geology and well data, the balanced geologic cross section was constructed. Using simple-shear model of the basin formation, the total amount of Miocene extension is calculated to be ca. $27 \mathrm{~km}$ and the total amount of late Neogene to Quaternary shortening is ca. $11 \mathrm{~km}$. The basin formation and shortening deformation are well explained by the tectonic inversion model and fault reactivation.
\end{abstract}

Key words: Seismic reflection, West Nagano Basin Fault, Itoigawa-Shizuoka Tectonic Line, Northern Fossa Magna, Active faults, Japan.

\section{Introduction}

Central Japan is geologically characterized by the intersection of three island arcs: the Northeast Japan, Southwest Japan, and Izu-Bonin arcs. This active geodynamical framework created the Neogene Fossa Magna (NFM) basin since the Miocene. This zone is considered one of the active tectonic areas in Japan, and thus its structure and tectonic evolution has attracted various research groups.

Since the beginning of the 20th century or even earlier, geological surveys have been conducted in this area. Till the 1960 s most of the studies were concentrated on understanding the geological structures (stratigraphy and tectonics) based on the surface geology (Morishita et al., 1957; Tanaka, 1958; Saito, 1961; Kato, 1992 and others). Later a second generation of scientists was eager to understand the geologic structure in depth using geophysical methods (Asano et al., 1969; Ikami et al., 1986; Sakai et al., 1996 and others). In spite of a large amount of geological and geophysical data, the deep geometry of the active faults around the NFM has been poorly understood. The common mid-point (CMP) seismic reflection method is a conventional technique to detect fine structure of the crust. In 1997, deep seismic reflection profiling was carried out across the western end of the NFM (Sato and Hirata, 1998) to reveal the deep geometry of active fault. In 1996 the Japan Na-

Copy right(c) The Society of Geomagnetism and Earth, Planetary and Space Sciences (SGEPSS); The Seismological Society of Japan; The Volcanological Society of Japan; The Geodetic Society of Japan; The Japanese Society for Planetary Sciences; TERRAPUB. tional Oil Corporation (JNOC) investigated the Nagano area in a western part of the NFM. We reprocessed this seismic data, focusing on detecting the deeper structure. In this paper, we introduce the reprocessed, seismic reflection profiles and discuss the deep geometry of the active faults and geologic structure of the NFM.

\section{Geologic Setting}

The NFM is located in the southern end of the northern Honshu rift system (Sato et al., 2004b) and is considered as a mega-scale half graben or depression, in relation to the opening of the Sea of Japan (e.g. Kato, 1992; Sato, 1994; Takano, 2002). This basin had been filled intensively and in a relatively short time considering the thick pile of sediment accumulated during the Neogene.

The investigated area is located in the middle part of the NFM, Nagano city in the NE and Omachi city in the SW (Fig. 1). The Mesozoic accretionary complex and Cretaceous granitic rocks, which are distributed in the western part of the study area (Hida Mountains), constitute the bedrock of the subsequent Neogene and the Quaternary formations. The basin-fill consists, in ascending order, of volcanic and volcaniclastic rocks and marine mudstone of Middle Miocene, distal to proximal turbidites of Upper Miocene, shallow marine to fluvial sediments of Pliocene, and colluvial and terrace deposits of the Quaternary at the top of the sedimentary column. The basin development is well described by Takano (2002). The Neogene basin-fill was deformed due to the shortening since Upper Miocene, which formed folds and reverse faults trending NE-SW. 


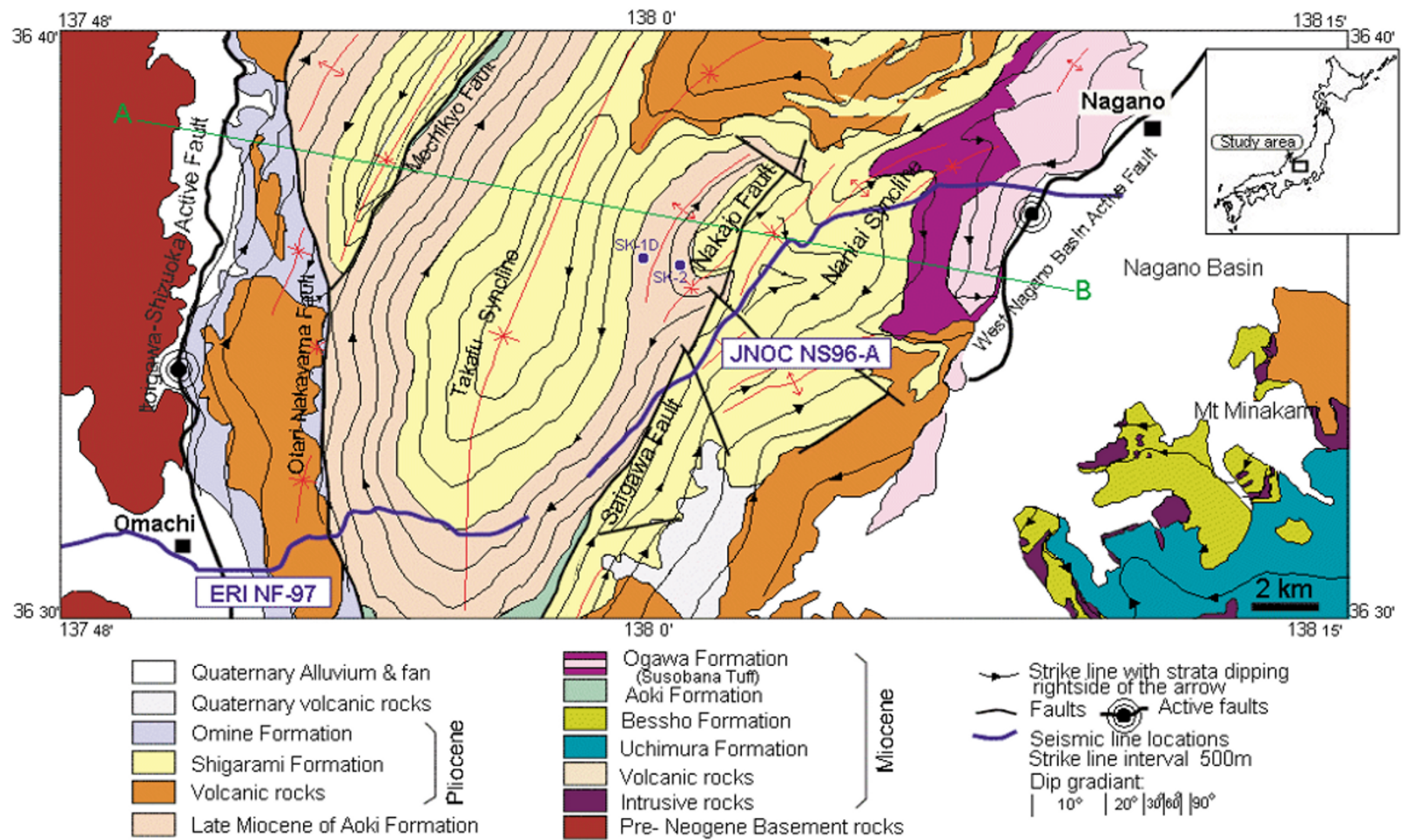

Fig. 1. Geological map with strike line contours of the Nagano and Omachi areas (Geological map is after Kato and Akahane (1986) and Kato et al (1989) and the trace of active faults is after Ikeda et al. (2002)).

The main geologic structure is marked by two synclines; the Naniai syncline in the east and Takafu syncline in the west. At the eastern flank of the Naniai syncline, the Western Nagano Basin active Fault (WNBF) is located. The vertical slip-rate of this fault is estimated to be more than 1.2 $\mathrm{mm} / \mathrm{y}$ (Oishi et al., 2001). The western end of the folded Neogene sedimentary rocks is bounded by the ItoigawaShizuoka Tectonic Line (ISTL) active fault system, trending $\mathrm{N}-\mathrm{S}$. The inferred average net-slip-rate from the displacement of strata of known age, which was obtained by drilling and shallow seismic reflection, is $4.4-5.4 \mathrm{~m} / \mathrm{kyr}$ over the last $28 \mathrm{ka}$ in Kamishiro (Matsuta et al., 2004).

\section{Data Acquisition and Processing \\ 3.1 Data acquisition}

To image the deep geometry of the active fault systems and the geological structure, we reprocessed seismic reflection data acquired from two seismic lines. In 1996 the Japan National Oil Corporation (JNOC) investigated the Nagano area through a network of seismic lines, among which we have used the NS96-A seismic line. Later in 1997, seismic reflection profiling was carried out by the Earthquake Research Institute (ERI) of the University of Tokyo across Omachi and ISTL (Sato and Hirata, 1998; NF-97 line; Fig. 1). The Japex Geosciences Institute (JGI Inc.) acquired both seismic profiles. The data acquisition parameters are shown in Table 1.

The NF-97 seismic line trends E-W over $17 \mathrm{~km}$, almost perpendicular to the geological structures. The seismic sources were four vibroseis trucks (IVI Y2400) and dynamite (three shot points of $20 \mathrm{~kg}$ of explosives). Signals were recorded with the digital telemetry system (G.DAPS-4:
Geophysical Data Acquisition and Processing System, series 4 of the JGI Inc.). The data was acquired with fixed 340 channels per shot.

The NS96-A line is located a few kilometers southwest of Nagano city and extends towards the SW, along the SaiGawa River over 19 km (Fig. 1). The seismic sources were four vibroseis trucks (IVI Y2400), and the recording instruments used were the JGI's G.DAPS-3. The total number of the active channel per shot was fixed to 256 channels.

\subsection{Processing}

Both lines were reprocessed using standard CMP methods by Super-X software package of JGI. As a first step, navigation data of each line were unified to the same format (UTM; Universal Transverse Mercator projection) and the CMP interval was set to 20 meters (Fig. 2).

Due to the difference in data acquisition parameters and instruments, the two lines were reprocessed separately. Static correction for the shallow weathering layer was applied based on refraction analysis of near-offset first arrivals using the time-term method. Referring to previous processing of 1998, the image quality has been improved, remarkably for the JNOC seismic line (NS96-A), where coherent and continuous reflections can be easily and consistently lined up. As a second step, two stacked sections (NF-97 and NS96-A) were merged into a single profile (Fig. 2) in order to fill the gap of seismic lines by migration process.

Despite of the difference in their strikes, E-W for the line NF-97 and NE-SW for the line NS96-A, we could merge both of them in a single seismic line. Applying the migration process, we have partially filled in the 1.5 -second (Two-Way Traveltime [TWT]) downward of the $4 \mathrm{~km}$ gap, but still reflections in the gap remained poor. This process 
Table 1. Data acquisition parameters for ERI NF-97 and JNOC NS96-A seismic lines.

\begin{tabular}{lcc}
\hline Seismic line & ERI NF-97 & JNOC NS96-A \\
Recording year & 1997 & 1996 \\
Length of seismic line & $17 \mathrm{~km}$ & $19 \mathrm{~km}$ \\
Record length & 10 second & 6 second \\
Sample rate & 4 m-second & 4 m-second \\
Instrument & G.DAPS-4 & G.DAPS-3 \\
Source type & Vibrators and Dynamite & Vibrators \\
No. of vibrator & 4 vehicles & 4 vehicles \\
Vibrators point (VP) interval & $50 \mathrm{~m}$ & $40 \mathrm{~m}$ \\
Sweeps/VP & 15 sweeps & 15 sweeps \\
Sweep length & 20 second & $26 \mathrm{~second}$ \\
Sweep frequency & $6-30 \mathrm{~Hz}$ & $10-60 \mathrm{~Hz}$ \\
Dynamite charge & $20 \mathrm{~kg} / \mathrm{shot}$ & - \\
No. of dynamite shot & 3 shots & - \\
Total shot points & 105 & 333 \\
Receiver type & Geophone UM-2 & Geophone HGS 5M-7 \\
Receiver group interval & $50 \mathrm{~m}$ & $20 \mathrm{~m}$ \\
Geophone interval & $2.78 \mathrm{~m}$ & $2.22 \mathrm{~m}$ \\
Channel No. & 340 & 256 \\
CMP interval & $25 \mathrm{~m}$ & $10 \mathrm{~m}$ \\
\hline
\end{tabular}

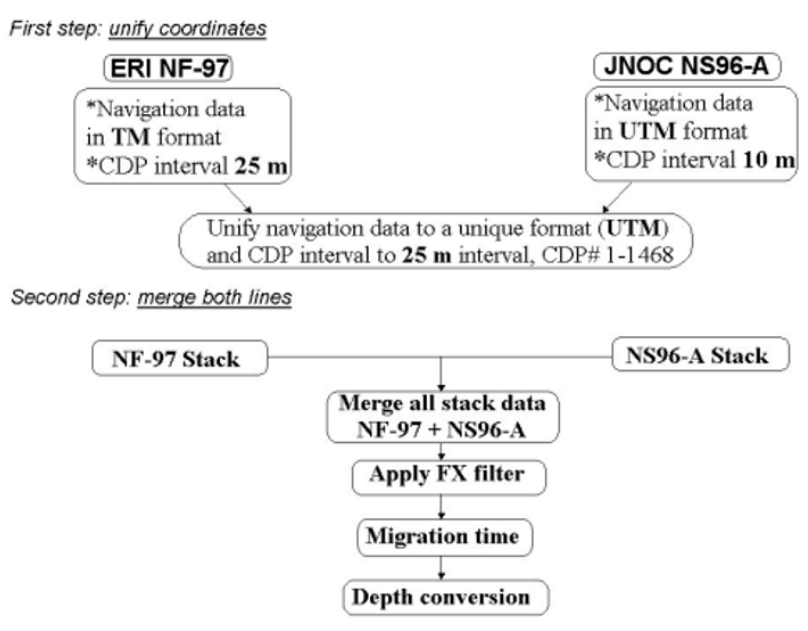

Fig. 2. Processing sequence of the merged line (NF-97 and NS96-A).

has made the possible connection between the structures of juxtaposed sides of the two lines.

\section{Geological Interpretation}

The merged seismic section (Fig. 3(A) and 3(B)) shows coherent reflections in the basin-fill of the NFM basin. The synclinal structure estimated from the surface geology well accords to the pattern of reflections. Based on the intersection between seismic lines and surface geology and using structural data (strike and dip of the strata), we have estimated the boundaries between the different members at depth. An increasing thickness of each of the different members (the Ronji member of the Ogawa Formation and the Asakawa member of the Aoki Formation) from the east to west has been revealed in the Naniai and Takafu Syn- clines. The test well logs, SK-1D and SK-2 (Figs. 1 and 4), located at the cross section of the Nagano geological map (Kato and Akahane, 1986), allow us to trace the boundaries between members of the Neogene sedimentary rocks. This also attests the remarkable increase of the thickness of the members from east to west, mentioned above.

The depth of the pre-Neogene basement has been estimated using the velocity model obtained by refraction analysis (Takeda et al., 2004). On the western part of the section, the location of the base of Neogene basin-fill is mainly determined by the above-mentioned results of the refraction analysis, as a top of 5.95-6.0 km/s P-wave velocity layer.

In the eastern part of the seismic section, the preNeogene basement is marked by poor reflections, while in the western part, reflections are more remarkable. This is probably related to a difference in nature of the basement rocks and/or the deformation, which the rocks had undergone. Such deformation seems to be stronger near the ISTL in the western part, where bands of tectonites (mylonite and cataclasite) were developed within the parent rocks. These rocks can be more reflective than the undeformed parent rocks (intact granite). The WNBF is marked by the discontinuity of the pattern of reflectors (Fig. 3(B) and zoom [c]). On the footwall of the fault, horizontal reflectors are represented down to ca. $2 \mathrm{~km}$. On the hanging wall, the eastern flank of the Naniai syncline shows constant westdipping reflectors. The deeper extension of the WNBF can be traced down to $4 \mathrm{~km}$ as bedding-slip fault and its overall geometry is very similar to "Out of the syncline thrust" (McClay, 1992).

At the western flank of the Naniai syncline, the geometry of the Saigawa fault is well represented by the seismic section. This fault is recognized as the boundary between westdipping reflectors (Late Miocene) on the hanging wall and 


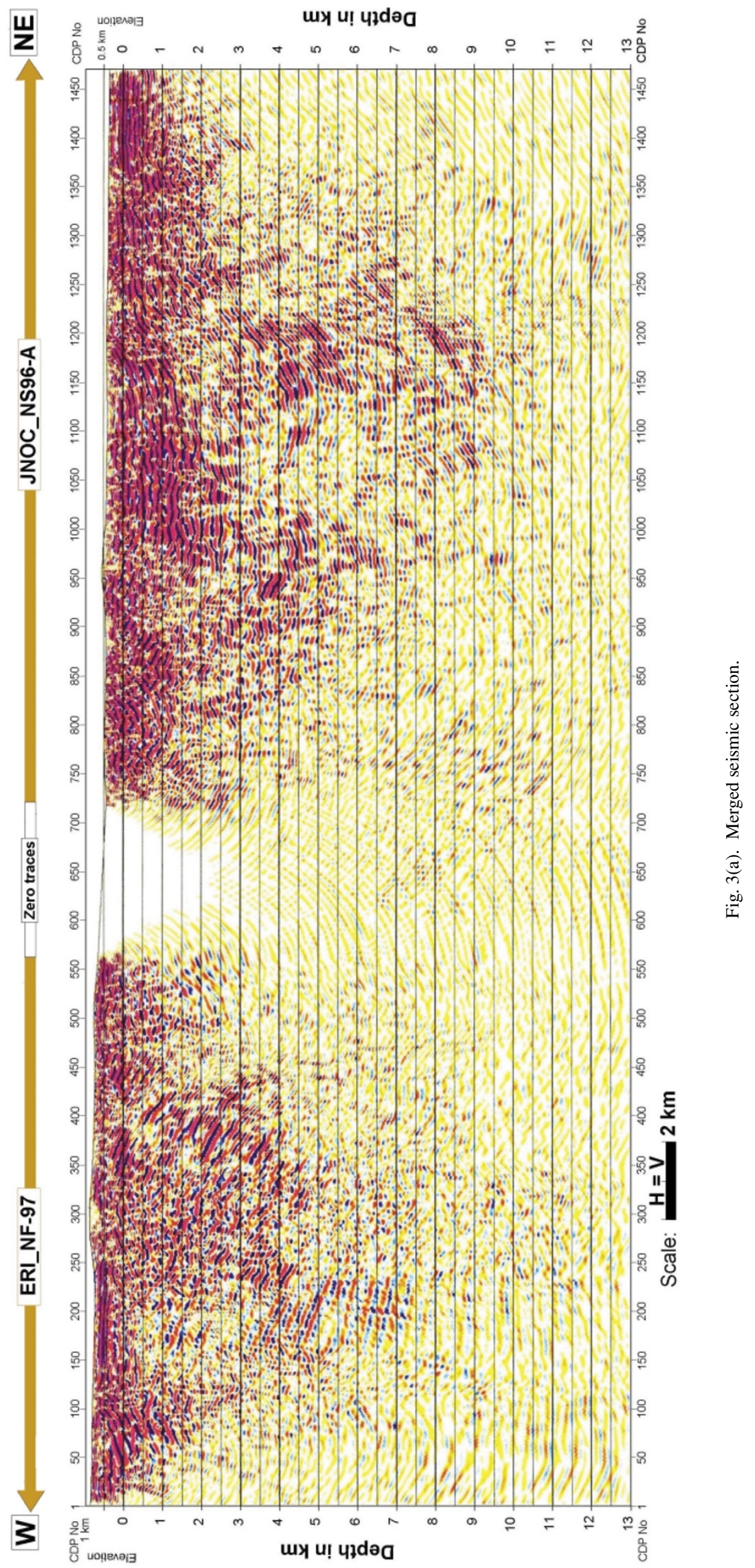



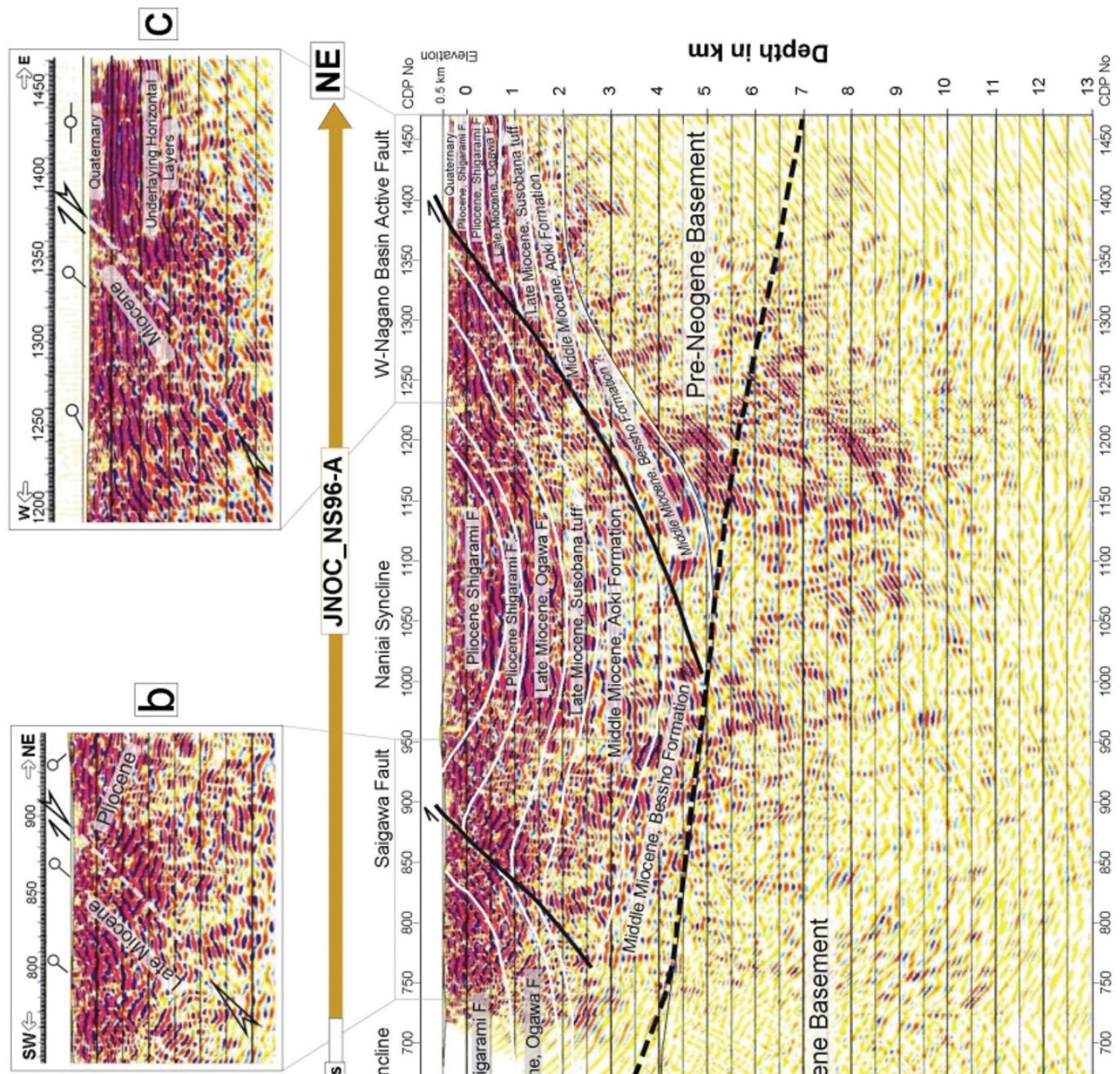

-2.

(o)

๑)

क

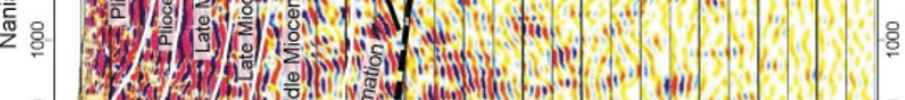

$\div$ 을

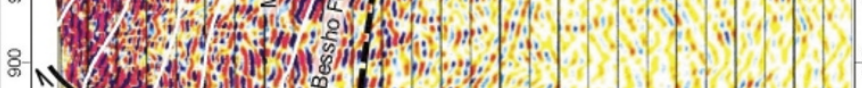

N

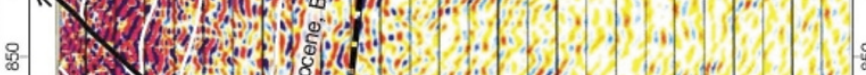

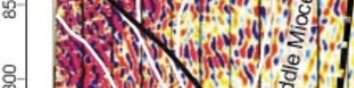

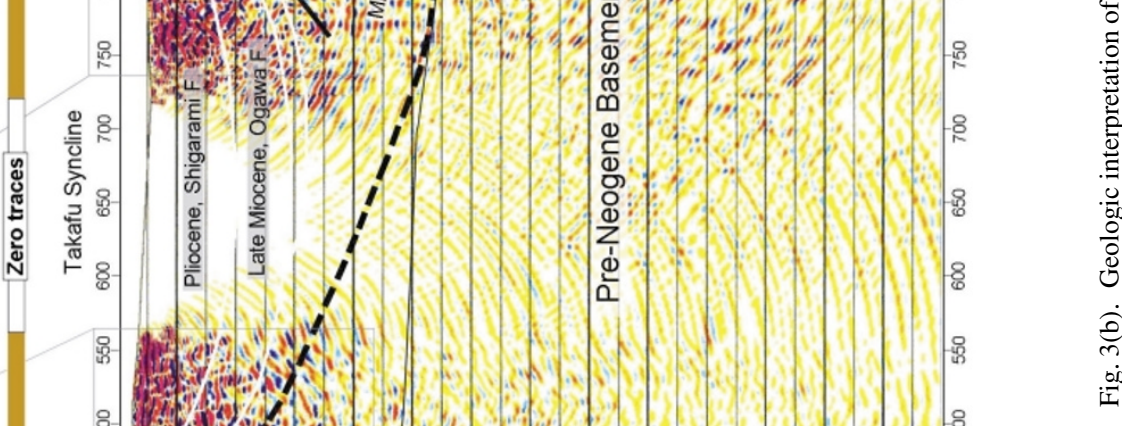

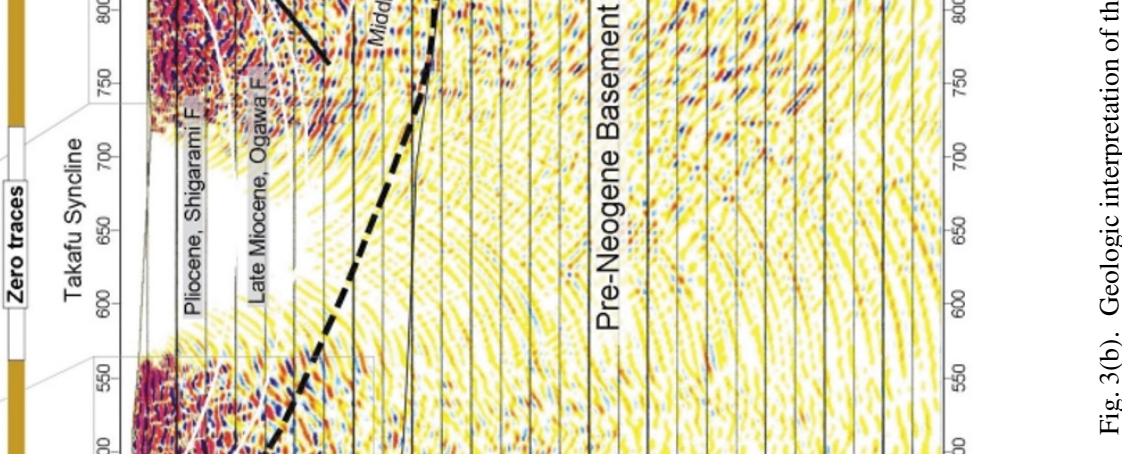

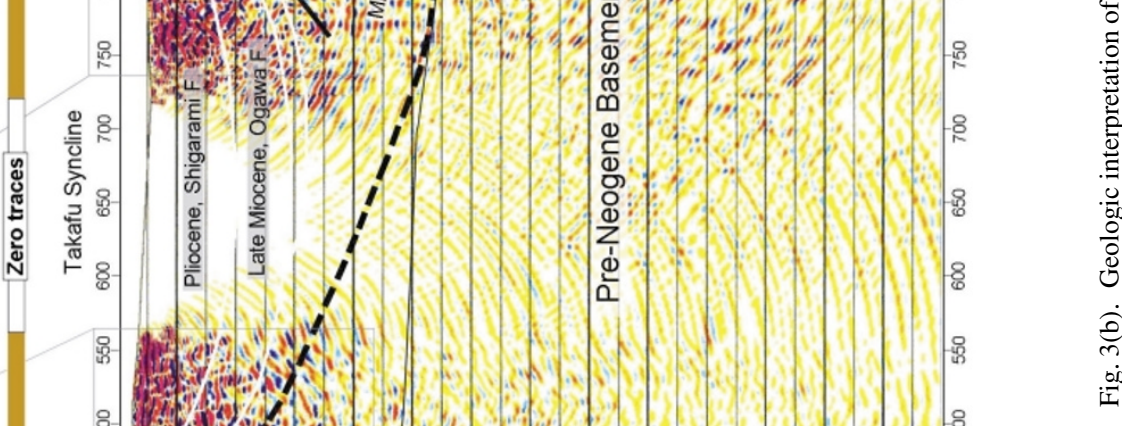

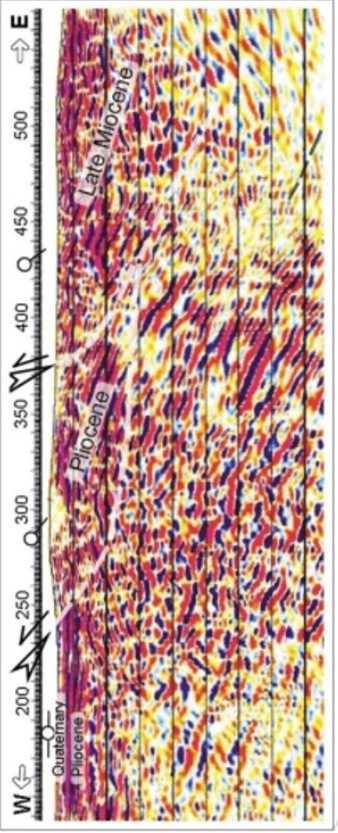

号

8-

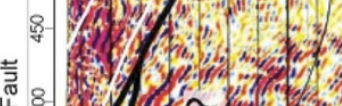

㝵

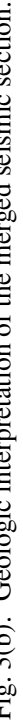

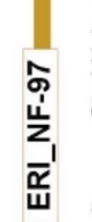

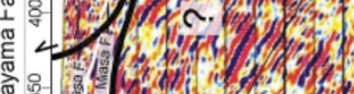

(2)

官
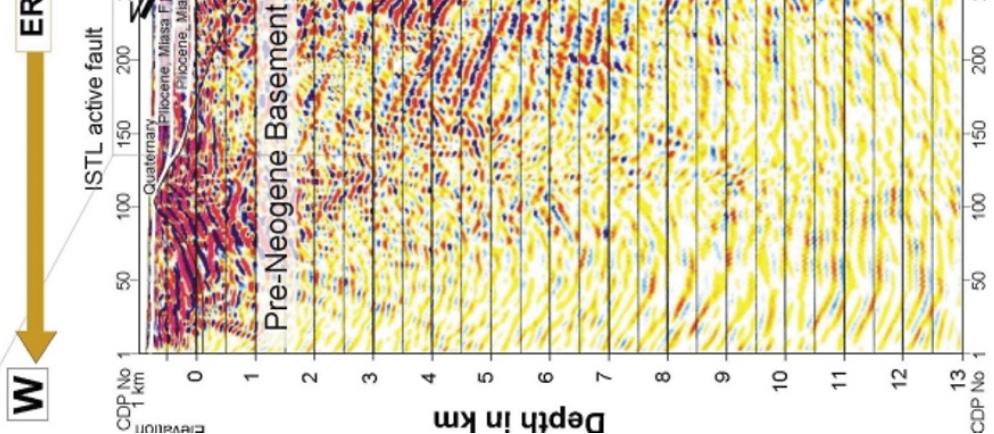
C. Present

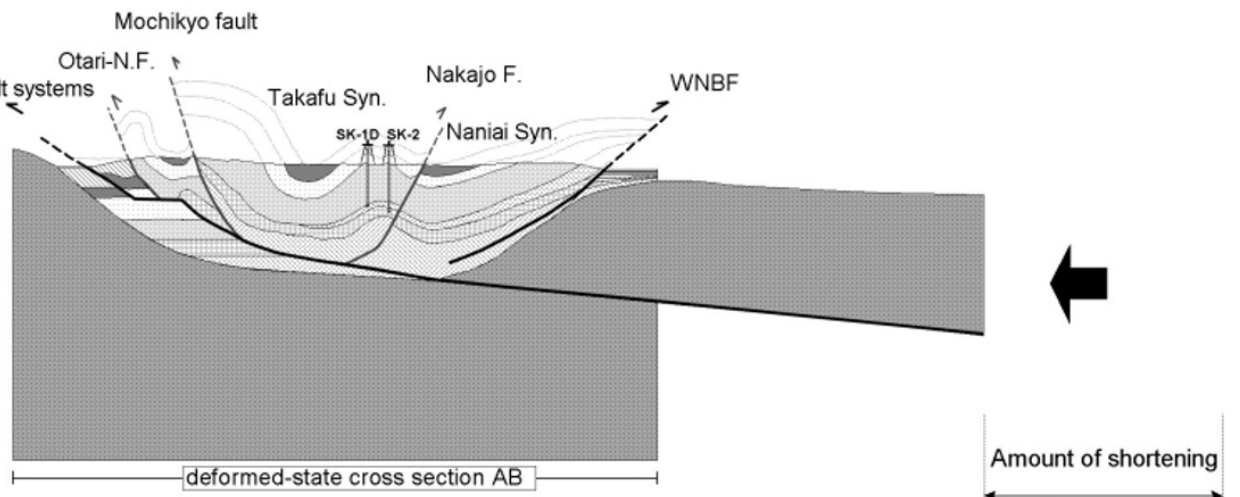

ca. $11 \mathrm{~km}$

\section{B. Rifting and Basin filling Miocene-Early Pliocene}
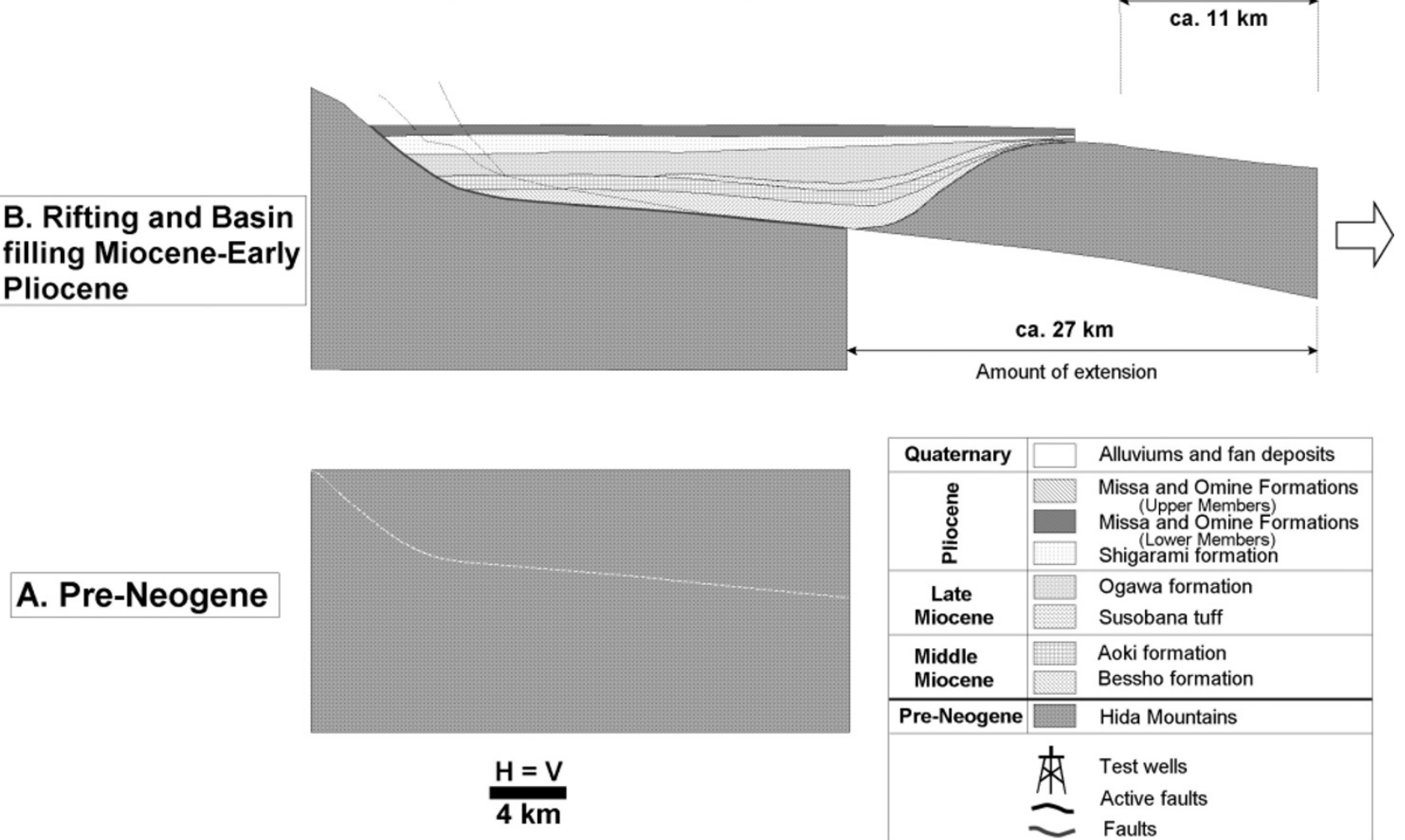

\begin{tabular}{|c|c|}
\hline Quaternary & Alluviums and fan deposits \\
\hline $\begin{array}{l}\stackrel{Ð}{\Phi} \\
\frac{0}{2}\end{array}$ & $\begin{array}{l}\text { Missa and Omine Formations } \\
\text { (Upper Members) } \\
\text { Missa and Omine Formations } \\
\text { (Lower Members) } \\
\text { Shigarami formation }\end{array}$ \\
\hline $\begin{array}{l}\text { Late } \\
\text { Miocene }\end{array}$ & $\begin{array}{l}\text { Ogawa formation } \\
\text { Susobana tuff }\end{array}$ \\
\hline $\begin{array}{l}\text { Middle } \\
\text { Miocene }\end{array}$ & $\begin{array}{l}\text { Aoki formation } \\
\text { Bessho formation }\end{array}$ \\
\hline \multirow[t]{2}{*}{ Pre-Neogene } & Hida Mountains \\
\hline & $\begin{array}{l}\text { Test wells } \\
\text { Active faults } \\
\text { Faults }\end{array}$ \\
\hline
\end{tabular}

Fig. 4. Model of the tectonic evolution of the northern Fossa Magana (Nagano and Omachi areas).

SE-dipping reflectors (Pliocene) on the footwall (Fig. 3(B) and zoom [b]). The apparent dip angle of this fault, estimated from the section is 45-50 degrees while the calculated true angle is 75 degrees to the west. The Takafu syncline, located west of the Naniai syncline, is also recognized in the seismic section. However, due to the steep dipping (almost vertical) of the Neogene strata at the western flank of the Takafu syncline, the acquired seismic waves can not be significant reflections. Hence, the pattern of reflection does not match the surface geology.

The ISTL active fault is identified as the boundary between the east-dipping reflectors (Pliocene) on the hanging wall and the horizontal reflectors (Pliocene and Quaternary) on the footwall (Fig. 3(B) and zoom [a]). Deeper extension of the fault is difficult to identify due to the strong eastdipping reflections, which are probably side-waves. According to the seismic profile (Sato et al., 2004a) located
$4 \mathrm{~km}$ south from NF-97, a flat-and-ramp geometry was demonstrated for the ISTL active fault. Thus, we inferred similar geometry, following the above-mentioned result.

\section{Model and Discussion}

Structural balancing is based on the intuitively satisfying concept that the interpreter must not create nor destroy volume during the interpretation process. Cross-section balancing is fundamental to correct geologic interpretations, the more complete the data and the better the interpretative techniques, the more likely that the balanced section will reflect reality (Tearpock and Bischke, 1991).

Using balanced cross-section methods, we can obtain the quantitative estimation of the amount of Miocene extension and the later shortening, and also more realistic fault geometry at depth. To construct a balanced cross-section, we have to choose a section parallel to the transport direction. 
As our seismic line does not satisfy this condition, especially the NS96-A line, we have set a new cross-section line (Fig. 1, section AB), which is perpendicular to the strike of faults and fold-axial-traces. All the available data, including the structural data of the surface geology (strike and dip of the strata), the interpreted seismic line and the well logs (SK-1D and SK-2; Fig. 1 after Kato and Akahane, 1986), were used to portray the balanced section (Fig. 4(C)). In this reconstruction we ignored the volume change derived from magmatic and plutonic activity. For the basin formation of the NFM, we used the simple-shear model proposed by Sato and Ikeda (1999) and Sato et al. (2004a). Based on this model, it has been estimated that the deeper part of the Miocene low-angle normal fault, which was formed during the rifting, was reactivated as a thrust in late Neogene and produced the shortening deformation in the basin-fill (Fig. 4).

The amount of Miocene extension during the basin formation is estimated to be ca. $27 \mathrm{~km}$ (Fig. 4(B)) and the total amount of Late Neogene to Quaternary shortening is ca. 11 km (Fig. 4(C)). The amount of shortening in Itoshizu 2002 seismic section (located $12 \mathrm{~km}$ south of the section A-B) is ca. $23 \mathrm{~km}$ (Sato et al., 2004a). The increase of the total amount of shortening southward is concordant to the decrease in the width of the folded zone to the south. The width of the folded zone along the section A-B (Figs. 1 and 4) is $25 \mathrm{~km}$, while along the seismic line of Itoshizu 2002, it is $10 \mathrm{~km}$. The obtained difference in the amount of shortening (ca. $12 \mathrm{~km}$ ), roughly coincides with the difference in the width of the folded zone (ca. $15 \mathrm{~km}$ ).

On the section A-B, the ISTL active fault and the WNBF are both active and producing a pop-up structure of the Miocene basin-fill. On this section (Fig. 4), it is estimated that the east-dipping low-angle fault, which is a direct extension of the ISTL active fault system, played an important role for the structural evolution of the NFM. From this point of view, the western Nagano basin fault is recognized as a wedge-thrust associated with the east-dipping master fault (ISTL). However, in a broader view, the late Quaternary faulting of the ISTL active fault is terminated to the north and alternatively the western Nagano basin active fault system extends further N-E direction. The location of the A-B section corresponds to the narrow zone where both faults are active. Thus, whether the western Nagano basin active fault shows similar deep fault geometry in the northeastern extension or not, remains a future problem.

\section{Conclusion}

The two CMP-reflection data acquired separately in the western and eastern parts were merged and reprocessed as a single seismic section across the middle part of the NFM. Through the migration processing, we could obtain a relatively continuous seismic section at depth. The reprocessed profile portrays the thick folded basin-fill and subsurface geometry of the active faults; the western Nagano basin active fault (WNBF) in the eastern part of the North Fossa Magna (NFM) and the Itoigawa-Shizuoka Tectonic Line (ISTL) active fault in the western part. The deep geometry of the WNBF, which has been described here for the first time, can be traced down to $4 \mathrm{~km}$, as reverse fault dipping $40^{\circ}$ to the west. In the western part, the ISTL active fault is presented as an emergent thrust dipping $30-35^{\circ}$ eastward. A geologic balanced cross-section has been constructed, and based on the simple-shear model of basin formation; we have proposed a model of the geological history of this part of the NFM. The amount of Miocene extension has been inferred to be ca $27 \mathrm{~km}$. By the reactivation of the deeper part of the Miocene basin-forming normal fault, the style of shortening deformation of the basin-fill has been successfully produced. The total amount of Late Neogene to Quaternary shortening has been inferred to be ca. $11 \mathrm{~km}$, which increases to the south.

Acknowledgments. We are grateful to Takeshi Ikawa, Taku Kawanaka and Tomonori Kawamura for their suggestions during seismic processing, and to Takaya Iwasaki, Yasutaka Ikeda and Nobuhisa Matsuta for their comments on the active tectonics and crustal structure. We would also like to thank the Japan National Oil Corporation (JNOC) for permitting us to use the seismic data. This research is supported by Grant-in-Aid for Scientific Research (no. 08404025, 14209004) and "Slip and Flow Processes in and below the Seismogenic Region" project provided by the Ministry of Education, Culture, Sports, Science and Technology, Japan.

\section{References}

Asano, S., K. Ichikawa, H. Okada, S. Kubota, H. Suzuki, M. Nogoshi, H. Watanabe, K. Seya, K. Noritomi, and K. Tazime, Explosion seismic observations in the Matsushiro Earthquake Swarm Area, Spec. Rep. Geol. Survey of Japan, 5, Part I, 1-162, 1969.

Ikami, A., T. Yoshii, S. Kubota, Y. Sasaki, A. Hasemi, T. Moriya, H. Miyamachi, R. Matsu'ura, and K. Wada, A seismic refraction profile in and around Nagano Prefecture, Central Japan, J. Phys. Earth, 34, 457-474, 1986.

Ikeda, Y., T. Imaizumi, M. Togo, K. Hirakawa, T. Miyauchi, and H. Sato (eds.), Atlas of Quaternary Thrust Faults in Japan, Univ. of Tokyo Press, Tokyo, 254 pp., 2002 (in Japanese).

Kato, H., Fossa Magna-A masked border region separating southwest and northeast Japan, Bull. Geol. Surv. Japan, 43, 1-30, 1992.

Kato, H. and S. Akahane, Geology of the Nagano District. Quadrangle Series Scale 1:50000, Geol. Surv. Japan, 122 pp., 1986 (in Japanese with English Abstract).

Kato, H., K. Mimura, T. Sato, and F. Takizawa, Geology of the Omachi District Quadrangle Series, Scale 1:50000, Geol. Surv. Japan, 111 pp., 1989 (in Japanese with English Abstract).

Matsuta, N., Y. Ikeda, and H. Sato, The slip-rate along the northern Itoigawa-Shizuoka tectonic line active fault system, central Japan, Earth Planets Space, 56, this issue, 1325-1332, 2004.

McClay, K. R., Glossary of thrust tectonics terms, in Thrust Tectonics, edited by K. R. McClay, 447 pp., Chapman \& Hall, London, 1992.

Morishita, A., J. Oguro, K. Sawai, K. Tanaka, S. Tanaka, and M. Uji, Geology of the southern part of Hijiri-yama, Nagano PrefectureOn the stratigraphy of the so-called 'Tochiku Facies' in the Ogawa Formation, Jour. Geol. Soc. Japan, 63, 159-166. 1957 (in Japanese with English abstract).

Oishi, K., A. Okada, and T. Nohara, Late Holocene faulting of the active faults along the western margin of the Nagano Basin based on the drilling survey at Nakano city, Nagano Prefecture, central Japan, Active Fault Research, 20, 52-58, 2001 (in Japanese with English abstract).

Saito, Y., A preliminary note on the structure-system of the Tertiary Formations in the northern part of the Fossa Magna, Bull. Fac. Educ. Shinshu Univ., 12, 99-108, 1961 (in Japanese with English abstract).

Sakai, S., T. Iwasaki, T. Iidaka, T. Yoshii, F. Yamazaki, and T. Kuwayama, The structure of the crust of Chubu region from the explosion observation, Earth Monthly, 18, 104-108, 1996 (in Japanese).

Sato, H., The relationship between late Cenozoic tectonic events and stress field and basin development in northeast Japan, J. Geophys. Res., 99, 22261-22274, 1994.

Sato, H. and N. Hirata, Deep geometry of active faults and the evolution of Japanese islands, Kagaku (Science), 68, 63-71, 1998 (in Japanese).

Sato, H. and Y. Ikeda, Major fault systems in northern Honshu, Japan, Earth Monthly, 21, 569-575, 1999a (in Japanese). 
Sato, H., T. Iwasaki, S. Kawasaki, Y. Ikeda, N. Matsuta, T. Takeda, N. Hirata, and T. Kawanaka, Formation and shortening deformation of a back-arc rift basin revealed by deep seismic profiling, central Japan, Tectonophysics, 388, 47-58, 2004a.

Sato, H., T. Yoshida, T. Iwasaki, T. Sato, Y. Ikeda, and N. Umino, Late Cenozoic tectonic development of the back arc region of central northern Honshu, Japan, revealed by recent deep seismic profiling, J. Jpn. Assoc. Petrol. Tech., 69, 145-154, 2004b (in Japanese with English abstract)

Takano, O., Changes in depositional systems and sequences in response to basin evolution in a rifted and inverted basin: An example from the Neogene Niigata-Shin'etsu basin, Northern Fossa Magna, central Japan, Sedimentary Geology, 152, 79-97, 2002.
Takeda, T., H. Sato, T. Iwasaki, N. Matsuta, S. Sakai, T. Iidaka, and A. Kato, Crustal structure in the northern Fossa Magna region, central Japan, modeled from refraction/wide-angle reflection data, Earth Planets Space, 56, this issue, 1295-1301, 2004.

Tanaka, K., Geology in the upper stream of Aida River in the middle part of Nagano Prefecture, Bull. Fac. Educ. Shinshu Univ., 12, 267-276, 1958 (in Japanese with English abstract).

Tearpock, D. J. and R. E. Bischke, Applied Subsurface Geological Mapping, Prentice-Hall, Inc, 811 pp., 1991.

D. Elouai (e-mail: edriss@hiroshima-u.ac.jp) H. Sato, N. Hirata, S Kawasaki, T. Takeshita, N. Kato, and T. Takeda 